\title{
Reformed Teaching and Learning in Science Education: A Comparative Study of Turkish and US Teachers
}

\author{
Burhan Ozfidan ${ }^{1}$, Baki Cavlazoglu ${ }^{2}$, Lynn Burlbaw ${ }^{1} \&$ Hasan Aydin ${ }^{3}$ \\ ${ }^{1}$ Texas A\&M University, Texas, USA \\ ${ }^{2}$ Karadeniz Technic University, Trabzon, Turkey \\ ${ }^{3}$ Yildiz Technical University, İstanbul, Turkey \\ Correspondence: Burhan Ozfidan, Texas A\&M University, Texas, USA. E-mail: b.ozfidan@tamu.edu
}

Received: December 4, 2016

Accepted: January 15, $2017 \quad$ Online Published: March 7, 2017

doi:10.5539/jel.v6n3p23

URL: http://doi.org/10.5539/jel.v6n3p23

\begin{abstract}
Achievements of educational reform advantage constructivist understandings of teaching and learning, and therefore highlight a shift in beliefs of teachers and apply these perceptions to the real world. Science teachers' beliefs have been crucial in understanding and reforming science education as beliefs of teachers regarding learning and teaching science impact their practice. The purpose of this study was to compare US and Turkish science teachers' beliefs about reformed learning and teaching science. As an instrument, we used Beliefs about Reformed Science Teaching and Learning (BARSTL) to collect and measure the teachers' beliefs regarding teaching and learning science education. We used an independent-sample t-test to analyze Turkish and American science teachers' beliefs about reformed learning and teaching science. In total, 38 science teachers from the US and 27 science teachers from Turkey participated in this study. Results showed that US science teachers' beliefs about reformed learning and teaching science are statistically higher than Turkish science teachers. The results of this study also indicated that although American and Turkish science education aim similar constructivist views on learning and teaching science, American science teachers hold more reformed beliefs in science teaching and learning than their Turkish colleagues.
\end{abstract}

Keywords: teaching and learning, Turkish, the US, science education, BARSTL

\section{Introduction}

Achieving reform-based education continues to be problematic in classrooms even though many teachers have ardently collaborated with university-based researchers and willingly joined in state and nationwide professional development chances to develop their own learning and teaching in science education (Luft, 2007; Luft, Roehrig, \& Patterson, 2003; Lotter, Harwood, \& Bonner, 2007). Current studies indicate that beliefs of teachers about the learning and teaching of science, the role of the teacher, and the authorized curriculum can hinder novel practice recommended during professional development trainings (Munby, Cunningham, \& Lock, 2000; Huberman \& Middlebrooks, 2000; Yerrick et al., 1997). Thus, understanding and identifying teachers' beliefs is important to the educational reform process (Bybee, 1993; Haney, Czerniak, \& Lumpe, 1996). For example, some experts in science education indicated that beliefs of teachers regarding the need to adhere to the authorized curriculum are very important to science teachers, yet publicly, these same teacher claim that they value a reform-oriented curriculum (Olson, 1981; Yerrick, Parke, \& Nugent, 1997).

Achievement of educational reform relies on teachers' understanding of constructivist learning and teaching, and therefore highlight the need for a shift in beliefs of teachers to apply these perceptions to the real world, i.e., the classroom (Bransford \& National Research Council, 2000). Fundamental philosophies of reform efforts and teacher beliefs are usually not well aligned. For instance, Kagan's (1992) study affirmed that numerous experimental studies indicate that teacher beliefs (a) express the nature of the teacher's belief about the nature to students' learning, (b) act as a filter through which they interpret teaching events, and (c) are stable and resistant to change. Several educators who teach science, accordingly, consider that the teachers' beliefs have a one-way and direct impact on the practice of teachers (Pajares, 1992). Nevertheless, current studies have exposed that the connection between the beliefs of teachers and practices have a symbiotic relationship with one another (Crawford, 2007; Smith \& Southerland, 2007). This study aimed to investigate the effect of science education on 
science teachers' beliefs about reformed learning and teaching science. This study examined teachers who teach in the United States and Turkey.

\section{Literature Review}

The theoretical and philosophical rationale of science teaching and learning is constructivism (Jones \& Carter, 2007; Crawford, 2007). The perspective is described by a hypothesis which "knowledge is not transmitted directly from one knower to another, but is actively built up by the learner" even though there are expansive type of ontological and epistemological viewpoints at play within recent constructivist understandings (Driver et al., 1994, p. 5). We, as human beings, create our own "mental models" and "rules" that we employ to create our own comprehension of the world and use to integrate our experiences. According to the constructivist perspective, learning science is an active, rational experiences of social process and "is something students do, not something that is done to them" (Bransford \& National Research Council, 2000, p. 35).

Furthermore, the National Science Standards highlight recommendations for the preparation of science teachers and for the teaching of science supporting a philosophical foundation to learn science (Achieve, 2013). According to American Association for the Advancement of Science (AAAS) (1989) in the standards, there is a primary request that any reforms of "teaching should be consistent with the nature of scientific inquiry" (p. 137). Satisfactory teaching of science, in other words, should (a) focus on the use and collection of evidence, (b) not distinct knowledge to discover, (c) engage students actively, and (d) start with questions about nature (NRC, 1996, p. 30). This viewpoint indicates that, "students must have 'minds-on' experiences - hands-on activities are not adequate" (p. 24). This sort of direction invokes teachers to provide opportunities for students to justify and explain their work to themselves and to each other, and assess the efficacy of their efforts - they [must learn to] evaluate the data they have collected, re-examining or collecting more if necessary, and making statements about the generalizability of their findings. They plan and make presentations to the rest of the class about their work and accept and react to the constructive criticism of others (NRC, 1996, p. 34).

Science teachers' beliefs have been crucial in understanding and reforming science education (Jones \& Carter, 2007; Crawford, 2007) as beliefs of teachers regarding learning and teaching science impact their practice (Sampson, Enderle, \& Grooms, 2013). Teachers' experiences also influence their beliefs in learning and teaching science. In the last two decades, many reforms involving Benchmarks for science literacy (AAAS, 2009) and Next Generation Science Standards (Achieve, 2013) have occurred in science education and programs within science education for teachers have aimed to teach these reforms to their pre-service teachers. In many programs within science education for teachers, science methods courses are designed to address new teaching and learning approaches in science, and increase pre-service teachers' knowledge and practice about reformed science teaching and learning. However, research in examining the influence of a science method course on pre-service teachers' beliefs about reformed learning and teaching science is limited.

\subsection{Science Education in the USA}

In the US, knowledge construction within social aspects is encouraged to develop and apply scientific concepts in education through a focus on the nature of science knowledge understanding. Science teachers in the US indicate that characterstics of scientific knowledge such as benefits of science education should be taught in schools and developed within an education framework (AAAS, 1993). Indeed, "emphasizing the nature of science as a way of knowing the world can also facilitate teachers' ability to focus on broader organizing science concepts that can engender student inquiries and less on vast assemblages of facts and formulas" (AAAS, 1993, p. ix). Reformed science education documents recommends that "we must reduce the sheer amount of material now being covered" (AAAS, 1993, p. xi), which highlights shallow learning associated with traditional views by placing "a premium on the ability to commit terms, algorithms, and generalizations to short-term memory and impedes the acquisition of understanding" (AAAS, 1993, p. xii).

Characteristics of teachers, according to NRC (2000), depended on reform-oriented notions that a teacher becomes an organizer "models the skills of scientific inquiry, as well as the curiosity, openness to new ideas and data, and skepticism that characterize science" (p. 33). Reform-minded teachers in the USA cultivate their students build their understanding and knowledge through more investigation-based activities that involve students in learning societies where the thinking and ideas of others are appreciated and distributed (Joram \& Gabriele, 1998).

Recent research shows that teachers' role in the classroom, student outcomes, the nature of science, and teacher beliefs regarding students and student learning are all fundamentals of teacher beliefs that have an important effect on teachers' teaching. Feldman, in a 2002 study, for instance, studied two teachers who taught physics in a 
high school and incorporated a reform-minded curriculum. Feldman (2002) affirmed "the teachers' beliefs of their role in their students' education were a contributing factor in their implementation of the curriculum" (p. 12).

\subsection{Science Education in Turkey}

Almost all schools around the world teach science as a core course. All countries have established and improved along distinctive paths because of unique political and cultural effects although subject and content classifications are roughly akin. To recognize the developmental path that has led each country, it is vital to study only the current worldwide pedagogy curriculum and education in science content. According to Turkmen and Bonnstetter (2007), Turkey has given distinct consideration and status to teach science like many other countries. Turkey connects Asia and Europe with a population of over 70 million. After the Ottoman Empire failed and toppled at the end of the First World War, the Republic of Turkey was founded in 1923. Developing a strong educational system was considered essential to Turkey be coming a "civilized" country in 1923 (Grossman, Onkol, \& Sands, 2007). However, the teaching of science has not been a significant part of the Turkish school curriculum.

Education in science does not have detailed historical background compared to the Turkey's historical background of science education, which, as a human enterprise and effort to describe the physical universe, could be traced back to the beginning of human kind (Keeves, 1998). Nevertheless, research in science education in Turkey is quite novel initiative. Researchers have been called upon to conduct more syntheses to better understand what happened in the past to guide future research (Osborne, 2007). According to Chang et al. (2010), it is essential not only to conduct significant research in science education to assist science teachers play better roles in improving scientific literacy and develop their practice in class, but also to recognize and focus on what has been studied in the past so as to understand what could be studied and investigated additionally in the future.

In Turkey, parents, students, teachers, and other educators since 1924 have complained concerning the education in science (Ozden, 2007). Many programs in science education were advanced by National Education Ministry in Turkey. Science education issues, unfortunately, were not completely solved although all other programs were attempted to apply with a tremendous excitement (Arslan, 2005). In elementary schooling programs from 1924 to 1974, there was not a "separate" science course in Turkey. The Turkish National Education Ministry included science subjects, entitled "Knowledge of Life" into the curriculum during that period of time. Science courses were given some importance and become separate within the curriculum after 1974 (Ozden, 2007).

National and international central exam results indicate concrete science achievement in Turkey. On the OKS (High School Entrance Examination) in 2005, there were 25 science questions, all of which came from students' school science courses; the average number of correctly answered questions was 4.79 (Kilic, 2002; Ozden, 2007). This exam was taken 786,284 students and 65,076 of them scored zero. This result indicates that $9 \%$ of students do not have any notion or knowledge regarding the questions that asked in the exam (Arslan, 2005). Likewise, within the same year, in 2005, 57,164 of students scored zero in OSS (the University Entrance Examination). Out of 45 questions, the average number of correct answers in science session was 3.8 (Ozden, 2007). Virtually $70 \%$ of students in Turkey cannot solve any science questions in high school or university entrance examinations. In terms of Turkish science education, this is a very disturbing and thought-provoking situation (Arslan, 2005).

International Association for the Evaluation of Educational Achievement (IEA) is an institution that makes international assessment and evaluation for different nations. According to Kilic (2002), in 1999, 38 different nations participated the Third International Mathematics and Science Study (TIMSS-R, 1999) and Turkey ranked $33^{\text {rd }}$ place among the 38 contributed nations since they had lower scores in the science part of the evaluations and assessments. All these parameters indicate that Turkish science education program results in low achievement and this condition should be considered problematic.

Comparing Turkey to the USA, according to the National Science Education Standards (1996), the first priority of science education in the USA is to teach "science for every one and to create scientifically literate citizens", however science classes are still problematic internationally. Baykul (1990), for instance, found that attitudes of students toward mathematics and science classes considerably diminished from grade 5 through grade 11 in Turkey.

The Relevance of Science Education (ROSE), an international project, aspires to determine vital aspects of technology and science education. The principal characteristic of this project is to identify aspects and considerations affecting motivation of students during technology and science instructions and analyze them. According to Sjoberg (2004), some of these aspects or factors are as follows: "attitudes towards scientists and 
expectations in future, attitudes towards different science and technology subjects, and variety of students' experiences about science and technology out of schools".

\section{Method}

Overall, we used a quantitative research method approach for this study. To compare Turkish and American science teachers' thoughts on teaching and learning science education, we used an independent-sample t-test.

\subsection{Instrument}

As an instrument, we used Beliefs about Reformed Science Teaching and Learning (BARSTL), to collect and measure the teachers' beliefs regarding teaching and learning science education. BARSTL consists of four subscales including (a) the nature of the science curriculum (NOSC), (b) characteristics of teachers and the learning environment (CTLE), (c) lesson design and implementation (LDI), and (d) how people learn about science (HPLS) (Sampson, Enderle, \& Grooms, 2013). The questionnaire included 5 demographic questions and 32 questionnaire items, which had 4-point Likert scale, ranging from 1 "strongly disagree" to 4 "strongly agree". The BARSTL was developed by Sampson, Enderle and Grooms who tested the instrument for construct and content validity. The authors concluded, after extensive testing, that the instrument has also has good theoretical coherence despite being divided into four different subscales. An exploratory factor analysis indicates that 32 items of the BARSTL do load on four distinct factors, and the way the items load reflects the four dimensions proposed by the authors; although in some instances, the participants in the study assigned different meanings to some of the items. In conclusion, this analysis suggests that the BARSTL has good overall content and construct validity (2013, p. 11).

In the development of the instrument, Sampson, Enderle and Grooms also established the instrument as reliable, writing: The two-internal consistency estimates of reliability that were computed for the BARSTL, a split-half coefficient expressed as a Spearmen-Brown corrected correlation and coefficient alpha, were .80 and .77 respectively. Therefore, these results support the expectation that the BARSTL is a reliable instrument for measuring reformed beliefs about the teaching and learning of science (2013, p. 12).

When the reliability coefficient was .70 or above, according to Gravetter and Wallnau (2000), an instrument is considered reliable. Therefore, we concluded that the findings of this study were reliable.

The survey instrument was also examined by a small group of American and Turkish scholars who were graduate students and have lived in the States over fifteen years. Besides this, two assistant professors and one full professor who was expert in the field of science education reviewed the survey instrument for content/face reliability. These all indicated that the instrument had excellent content validity.

\subsection{Data Collection}

Data was collected from Turkish and American science teachers. After we prepared the survey instrument on qualtrics, we sent the link of the survey to the participants in the US and Turkey. Two faculty members in Turkey helped us reach the Turkish science teachers and collect the data. We also used science faculty members' networking at Texas A\&M University to collect the data from the US science teachers.

\subsection{Participants}

We collected all our data from science teachers in various public schools. A total of 55 science teachers participated the study. There were 38 science teachers actively teaching in US public schools. The other 27 participants were from Turkey and actively working in Turkish public schools. The population of teachers was not randomly selected but use a snowball technique to identify teachers. For the US participants, we used our science faculties' networking with other institutions. For Turkish participants, we used our own personal network in Turkey.

\subsection{Data Analysis}

To compare Turkish and American science teachers' beliefs about reformed teaching and learning science, we used an independent-sample t-test. We randomly sorted the data through the SPSS into two groups, 1 and 2. Group 1 (the experimental group) consists of US beliefs of science teachers regarding teaching and learning and group 2 (the control group) consists of Turkish science teachers' beliefs about teaching and learning in science education. We concluded by measuring how well the subjects perform on the series of tasks under their respective conditions. Any difference between the effects of the two types of perspectives should show up as a difference between the mean levels of performance for group 1 and group 2. 


\section{Findings}

Overall, this study's scores showed a significant difference for science teachers' beliefs in the US (M=95.50, $\mathrm{SD}=5.83)$ and in Turkey $(\mathrm{M}=87.00, \mathrm{SD}=5.48)$ conditions; $\mathrm{t}(63)=5.94, \mathrm{p}=0.01$. More specifically, we found a significant difference in the scores for How People Learn about Science (HPL) in the US (M=22.76, SD=2.37) and in Turkey $(\mathrm{M}=20.22, \mathrm{SD}=2.34)$ conditions; $\mathrm{t}(63)=4.27, \mathrm{p}=0.00$. We found a significant difference in the scores for Lesson Design and Implementation (LDI) in the US $(M=23.82, S D=2.25)$ and in Turkey $(M=22.81$, $\mathrm{SD}=2.35$ ) conditions; $\mathrm{t}(63)=1.73, \mathrm{p}=0.09$. We found a significant difference in the scores for Teachers and the Learning Environment (CHAR) in the US $(M=25.18, S D=2.31)$ and in Turkey $(M=22.81, S D=2.69)$ conditions; $\mathrm{t}(63)=3.80, \mathrm{p}=0.00$. We also found a significant difference in the scores for the Nature of the Science Curriculum (NOSC) in the USA $(\mathrm{M}=23.74, \mathrm{SD}=1.66)$ and NOS in Turkey $(\mathrm{M}=21.15, \mathrm{SD}=1.41)$ conditions; $\mathrm{t}(63)=6.61$, $\mathrm{p}=0.01$. Specifically, our results indicate that teachers' teaching and knowledge of science education in Turkey is problematic compared to the US.

Table 1. Group statistics

\begin{tabular}{llllc}
\hline & Group & $\mathbf{N}$ & Mean & Std. Deviation \\
\hline \multirow{2}{*}{ HPL } & US & 38 & 22.76 & 2.365 \\
& Turkish & 27 & 20.22 & 2.342 \\
\multirow{2}{*}{ LDI } & US & 38 & 23.82 & 2.252 \\
& Turkish & 27 & 22.81 & 2.354 \\
\multirow{2}{*}{ CHAR } & US & 38 & 25.18 & 2.312 \\
& Turkish & 27 & 22.81 & 2.690 \\
\multirow{2}{*}{ NOSC } & US & 38 & 23.74 & 1.655 \\
& Turkish & 27 & 21.15 & 1.406 \\
\multirow{2}{*}{ TOTAL } & US & 38 & 95.50 & 5.830 \\
& Turkish & 27 & 87.00 & 5.477 \\
\hline
\end{tabular}

Table 2. Independent samples test

\begin{tabular}{|c|c|c|c|c|c|c|c|c|c|c|}
\hline & & \multicolumn{2}{|c|}{$\begin{array}{c}\text { "Levene's Test for } \\
\text { Equality of Variances }\end{array}$} & \multicolumn{7}{|c|}{ t-test for Equality of Means } \\
\hline & & \multirow{2}{*}{$\mathbf{F}$} & \multirow{2}{*}{ Sig. } & \multirow{2}{*}{$\mathbf{t}$} & \multirow{2}{*}{ df } & \multirow{2}{*}{ Sig. (2-tailed) } & \multirow{2}{*}{$\begin{array}{c}\text { Mean } \\
\text { Difference }\end{array}$} & \multirow{2}{*}{$\begin{array}{l}\text { Std. Error } \\
\text { Difference }\end{array}$} & \multicolumn{2}{|c|}{$\begin{array}{c}95 \% \text { Confidence Interval of } \\
\text { the Difference }\end{array}$} \\
\hline & & & & & & & & & Lower & Upper \\
\hline \multirow[t]{2}{*}{ HPL } & Equal variances assumed & .026 & .873 & 4.286 & 63 & .000 & 2.541 & .593 & 1.356 & 3.726 \\
\hline & Equal variances not assumed & & & 4.293 & 56.474 & .000 & 2.541 & .592 & 1.355 & 3.726 \\
\hline \multirow[t]{2}{*}{ LDI } & Equal variances assumed & .981 & .326 & 1.733 & 63 & .088 & 1.001 & .578 & -.153 & 2.155 \\
\hline & Equal variances not assumed & & & 1.720 & 54.595 & .091 & 1.001 & .582 & -.166 & 2.168 \\
\hline \multirow[t]{2}{*}{ CHAR } & Equal variances assumed & .667 & .417 & 3.804 & 63 & .000 & 2.369 & .623 & 1.125 & 3.614 \\
\hline & Equal variances not assumed & & & 3.707 & 50.651 & .001 & 2.369 & .639 & 1.086 & 3.653 \\
\hline \multirow[t]{2}{*}{ NOSC } & Equal variances assumed & .919 & .341 & 6.605 & 63 & .000 & 2.589 & .392 & 1.805 & 3.372 \\
\hline & Equal variances not assumed & & & 6.791 & 60.910 & .000 & 2.589 & .381 & 1.826 & 3.351 \\
\hline \multirow[t]{2}{*}{ TOTAL } & Equal variances assumed & .845 & .362 & 5.938 & 63 & .000 & 8.500 & 1.431 & 5.640 & 11.360 \\
\hline & Equal variances not assumed" & & & 6.002 & 58.203 & .000 & 8.500 & 1.416 & 5.665 & 11.335 \\
\hline
\end{tabular}

The findings indicated that reformed beliefs about science teaching and learning in the United States are statistically higher than teachers who are from Turkey. Particularly, some of the subscale scores such as HPLS 
(how people learn about science), CTLE (characteristics of teachers and the learning environment), and NOSC (the nature of the science curriculum) we found from the US science teachers are significantly higher than Turkish science teachers' beliefs about science teaching and learning. Nonetheless, the subscale of LDI (lesson design and implementation) no significant differences were found between the US and Turkish science teachers even though the US teachers' scores are considerably higher than Turkish.

\section{Conclusions and Recommendations}

The results of this study revealed that although American and Turkish science education have similar constructivist views on learning and teaching science, American science teachers hold more reformed beliefs in the subscales of HPLS, CTLE, and NOSC than their Turkish colleagues. We recommend Turkish stakeholders in science education taking actions to improve Turkish perspective of science teachers about reformed science teaching and learning and US stakeholders continue actions to enhance American science teachers' philosophies regarding reformed science teaching and learning.

Findings indicate that American science teachers work independently and collaboratively. They use effective pre-reading strategies and analyze textual information critically. They also use technology appropriately to manage, analyze, and organize information. We found that they critically summarize, outline, paraphrase, annotate texts whenever appropriate to increase understanding. In making assignments in their classes throughout the school year, they embed new ways of learning complex materials. We encourage working along with a team since they believe teamwork is one of the ways to be successful. However, we found that science teachers in Turkey do not use technology frequently and they do not encourage their students to work with a peer.

Teachers should design lessons in a way that encourages children to learn novel content through questioning instead of through a reading, watching a demonstration, or listening to a lecture. Teachers should give students opportunities to examine, discuss, and challenge ideas with their peers during a lesson. Science teachers should explain complex ideas simply and clearly to make them understand easily. The curriculum in science education needs to allow students to investigate and cherish alternative modes of problem solving or investigation. This curriculum needs to assist students improve the reasoning habits and skills of mind necessary to do science. A good curriculum for a science education needs to focus on how science affects people and societies, and the nature and history of science.

This study indicates that the beliefs we identified above have a big impact on classroom action along with practical knowledge. These beliefs consisted of intuitional thoughts and assumptions regarding the learning process of students, the nature of knowledge, teaching and teachers, and the curriculum goal that teachers foster before and over the course of their career. To be successful in science education reform, according to our study, the in-service and pre-service teachers' ability to integrate reform beliefs into their practice is vital if the current science education reform movement's philosophy is to be realized.

\section{References}

American Association for the Advancement of Science (AAAS). (1989). Project 2061: Science for all Americans. Washington, DC.: AAAS.

American Association for the Advancement of Science. (2009). Benchmarks for science literacy. New York, NY: Oxford University Press.

Arslan, C. (2005). Egitimde Reform (Reform in Education). Ankara University, Institute of Educational Sciences Publications, Ankara.

Achieve. (2013). Next Generation Science Standards. Retrieved from $\mathrm{http}: / / \mathrm{www}$. nextgenscience.org/next-generation-science-standards

Bransford, J., \& National Research Council (U.S.). (2000). How People Learn: Brain, Mind, Experience, and School. Washington, D.C.: National Academies Press.

Bybee, R. W. (1993). Leadership, responsibility, and reform in science education. Science Educator, 2, 1-9.

Chang, Y. H., Chang, C. Y., \& Tseng, Y. H. (2010). Trends of science education research: An automatic content analysis. Journal of Science Education and Technology, 19(4), 315-331. https://doi.org/10.1007/s10956-009-9202-2

Crawford, B. (2007). Learning to teach science in the rough and tumble of practice. Journal of Research in Science Teaching, 44, 613-642. https://doi.org/10.1002/tea.20157 
Driver, R., Asoko, H., Leach, J., Mortimer, E., \& Scott, P. (1994). Constructing scientific knowledge in the classroom. Educational Researcher, 23, 5-12. https://doi.org/10.3102/0013189X023007005

Grossman, G. M., Onkol, P. E., \& Sands, M. (2007). Curriculum reform in Turkish teacher education: Attitudes of teacher educators towards change in an EU candidate nation. International Journal of Educational Development, 27, 138-150. https://doi.org/10.1016/j.ijedudev.2006.07.005

Feldman, A. (2002). Multiple perspectives for the study of teaching: Knowledge, understanding and being. Journal of Research in Science Teaching, 39, 1032-1055. https://doi.org/10.1002/tea.10051

Haney, J. J., Czerniak, C. M., \& Lumpe, T. M. (1996). Teacher beliefs and intentions regarding the implementation of science education reform strands. Journal of Research in Science Teaching, 33, 971-993. https://doi.org/10.1002/(SICI)1098-2736(199611)33:9\%3C971::AID-TEA2\%3E3.0.CO;2-S

Huberman, M., \& Middlebrooks, S. (2000). The dilution of inquiry: A qualitative study. Qualitative Studies in Education, 13, 281-304. https://doi.org/10.1080/09518390050019686

Joram, E., \& Gabriele, A. (1998). Preservice teachers' prior beliefs: Trans-forming obstacles into opportunities. Teaching and Teacher Education, 14(2), 175-191. https://doi.org/10.1016/S0742-051X(97)00035-8

Kılıç, G. B. (2002). Dünyada ve Türkiye'de fen ögretimi (Science teaching in Turkey and in the world). V. Ulusal Fen Bilimleri ve Matematik Egitimi Kongresi, ODTÜ, Ankara.

National Research Council (NRC). (2000). Inquiry and the national science education standards. Washington, DC: National Academy Press.

National Research Council (NRC). (1996). National science education standards. Washington, DC: National Academy Press.

Jones, M. G., \& Carter, G. (2007). Science teacher attitudes and beliefs. In S. Abell, \& N. Lederman (Eds.), Handbook of research on science education (pp. 1067-1104). Mahwah, NJ: Lawrence Erlbaum Associates.

Kagan, D. (1992). Implications of research on teacher belief. Educational Psychologist, 27(1), 65-90. https://doi.org/10.1207/s15326985ep2701_6

Lotter, C., Harwood, W., \& Bonner, J. (2007). The influence of core teaching conceptions on teachers' use of inquiry teaching practices. Journal of Research in Science Teaching, 44(9), 1318-1347. https://doi.org/10.1002/tea.20191

Luft, J. (2007). Minding the gap: Needed research in beginning/newly qualified science teachers. Journal of Research in Science Teaching, 44(4), 532-537. https://doi.org/10.1002/tea.20190

Luft, J., Roehrig, G., \& Patterson, N. (2003). Contrasting landscapes: A comparison of the impact of different induction programs on beginning secondary science teachers' practices, beliefs, and experiences. Journal of Research in Science Teaching, 40(1), 77-97. https://doi.org/10.1002/tea.10061

Munby, H., Cunningham, M., \& Lock, C. (2000). School science culture: A case study of barriers to developing $\begin{array}{lllll}\text { professional } \quad \text { knowledge. } & \text { Science }\end{array}$ https://doi.org/10.1002/(SICI)1098-237X(200003)84:2\%3C193::AID-SCE4\%3E3.0.CO;2-K

Olson, J. K. (1981). Teacher influences in the classroom: A context for understanding curriculum translation. Instructional Science, 10, 259-275. https://doi.org/10.1007/BF00139803

Osborne, J. (2007). In praise of armchair science education. E-NARST News, 50(2), 8-11.

Ozden, M. (2007). Problems with science and technology education in Turkey. Eurasia Journal of Mathematics, Science \& Technology Education, 3(2), 157-161.

Pajares, M. F. (1992). Teachers' beliefs and educational research: Cleaning up a messy construct. Review of Educational Research, 62, 307-332. https://doi.org/10.3102/00346543062003307

Sampson, V., Enderle, P., \& Grooms, J. (2013). Development and initial validation of the Beliefs about Reformed Science Teaching and Learning (BARSTL) Questionnaire. School Science and Mathematics, 113(1), 3-15. https://doi.org/10.1111/j.1949-8594.2013.00175.x

Sjoberg, S. (2004). Science Education: The Voice of the Learners. Contribution to the conference on Increasing Human Resources for Science and Technology in Europe EU, Brussels.

Smith, L., \& Southerland, S. (2007). Reforming practice or modifying reforms? Journal of Research in Science Teaching, 44(3), 396-423. https://doi.org/10.1002/tea.20165 
Turkmen, L., \& Bonnstetter, R. J. (2007). Influences of some philosophical approaches in the historical development of Turkish science education. Science Education International, 18(1), 139-151.

Yerrick, R., Parke, H., \& Nugent, J. (1997). Struggling to promote deeply rooted change: The "filtering effect" of teachers' beliefs on understanding a transformational view of teaching science. Science Education, 81, 137-157. https://doi.org/10.1002/(SICI)1098-237X(199704)81:2\%3C137::AID-SCE2\%3E3.0.CO;2-G

\section{Copyrights}

Copyright for this article is retained by the author(s), with first publication rights granted to the journal.

This is an open-access article distributed under the terms and conditions of the Creative Commons Attribution license (http://creativecommons.org/licenses/by/4.0/). 